\title{
The dynamics of photosynthetic parameters of Phaseolus vulgaris and Vicia fabo under strong cadmium stress
}

\author{
Irena Januškaitienè \\ Vytautas Magnus University \\ Vileikos str. 8, \\ LT-44404 Kaunas, Lithuania
}

\begin{abstract}
One of the most toxic metals is cadmium, which inputs include those from commercial fertilizers, sewage sludge and other wastes used as soil amendments and also atmospheric deposition. The aim of this experiment was to study the dynamics of photosynthetic parameters of bean (Phaseolus vulgaris L.) and broad bean (Vicia fabo L.) under strong cadmium stress effect. Plants were sown in a neutral $(\mathrm{pH}$ 6.0-6.5) peat substrate, when 2 nd true leaf unfolded, growth substrate was watered with $6 \mathrm{mM}$ concentration $\mathrm{CdSO}_{4}$ solution. Gas exchange parameters (photosynthetic rate $(\mathrm{Pn})$, transpiration rate $(\mathrm{Tn})$, intercellular $\mathrm{CO}_{2}$ concentration $(\mathrm{Ci})$ and water use efficiency (WUE)) were measured every day with portable photosynthesis system LI-6400. Content of photosynthetic pigments was analyzed in acetone extract using a spectrophotometer on the last 5th day of the experiment. On the first day of treatment the $\mathrm{Pn}$ of $\mathrm{Cd}$ treated $P$. vulgaris plants decreased only by $4.3 \%$ and statistically insignificant, while Pn of $V$. fabo decreased by $35.9 \%$ ( $\mathrm{p}<0.05$ ). Pn of P. vulgaris was decreasing till 3rd day after treatment, when it was $96 \%(\mathrm{p}<0.05)$ lower compared to reference treatment. On the contrary, the lowest Pn of Cd treated V. fabo plants was on the first day and it started to increase from the second day till the last one. WUE of Cd treated P. vulgaris was decreasing till the third day too and it improved a little on the last one, but still it was $54 \%(\mathrm{p}<0.05)$ lower compared to the reference. While WUE of $V$. fabo increased by $23 \%(\mathrm{p}<0.05)$ and $16 \%(\mathrm{p}>0.05)$ on the first and the last day after Cd treatment, respectively compared to the reference. The changes, detected on the last day of the experiment, of chorophyll $a$ and $b$ ratio were different too, i. e. for $P$. vulgaris it decreased by $5.7 \%(\mathrm{p}>0.05)$, and for $V$. fabo - increased by $1.4 \%(\mathrm{p}>0.05)$ compared to the reference. Also decrease of dry biomass of $P$. vulgaris was greater than that of V. fabo.
\end{abstract}

Key words: stress dynamics, $\mathrm{Cd}$, net photosynthesis, intercellular $\mathrm{CO}_{2}$ concentration, transpiration, water use efficiency, photosynthetic pigments, dry biomass, Phaseolus vulgaris, Vicia fabo

\section{INTRODUCTION}

Cadmium $(\mathrm{Cd})$ is a toxic trace pollutant for humans, animals and plants, which enters the

\footnotetext{
* Corresponding author. E-mail: I.Januskaitiene@gmf.vdu.lt
}

environment mainly from anthropogenic processes and is then transferred to the food chain (Templeton and Liu, 2010). It is easily taken up by roots and transported to other parts of the plant (Gallego et al., 2012; Saidi et al., 2014). When soil Cd concentrations exceed $0.5 \mathrm{mg} / \mathrm{kg}$, 
it is generally considered evidence of soil pollution. Cd is translocated into plant tissues due to an interference with essential elements, such as calcium $(\mathrm{Ca})$ and potassium $(\mathrm{K})$ (Uraguchi et al., 2009), and it becomes toxic when it accumulates at high concentrations in plant tissues (Hassan et al., 2013).

$\mathrm{Cd}$ is an effective inhibitor of photosynthesis (Mohamed et al., 2012). A linear relationship between photosynthesis and inhibition of transpiration was observed in clover, lucerne, and soybean that suggest $\mathrm{Cd}$ inhibited stomatal opening (Barcelo, Poschenrieder, 1990). Cd damages the photosynthetic apparatus, in particular the light harvesting complex II and photosystems I and II (Siedlecka et al., 1997). The inhibition of root $\mathrm{Fe}$ (III) reductase induced by $\mathrm{Cd}$ leads to Fe(II) deficiency which seriously affects photosynthesis (Alkantara et al., 1994). Cd also causes alteration in leaf gas exchange (LópezCliment et al., 2011) stomatal closure in higher plants (Poschenrieder et al., 1989) and an overall inhibition of photosynthesis (Mohamed et al., 2012). In A. thaliana Cd altered the activity of photosynthetic apparatus (Mohamed et al., 2012) while decreasing the potential quantum yield of PSII (Maksymiec et al., 2007). Similarly, the synthesis and level of pigments are decreased in other plant species under the influence of $\mathrm{Cd}$ (Mohamed et al., 2012; Irfan et al., 2013).

Cadmium has no biological function and is not even essential for plant growth. Being water soluble, $\mathrm{Cd}^{2+}$ ion can be easily absorbed in tissues and can cause various phytotoxic visible symptoms (Hu et al., 2009; Valentovicova et al., 2010). Despite cadmium toxicity, plants have evolved a complex array of mechanisms to maintain optimal cadmium levels and avoid the detrimental effects of excessively high concentrations. Among the mechanisms, the activity of ROS-scavenging enzymes, including superoxide dismutase (SOD), catalase (CAT) and ascorbate peroxidase (APX), is considered as the most important protective mechanism to minimise the metal-induced oxidative damage in several plants (Parlak, Yilmaz, 2013; Li et al., 2014).

Different plant species and varieties show a wide range of plasticity in $\mathrm{Cd}$ tolerance, from a high degree of sensitivity to a hyper-accumulating phenotype of some tolerant plants (Saidi et al., 2014). Legume plants are less tolerant to Cd toxicity than cereals and grasses. Although there have been many reports on the photochemical and biochemical events occurring in photosynthesis during Cd toxicity, a lot of contradictory data can be found in the literature (Popova et al., 2009). For instance, in leaves of Brassica napus Cd leads to a reduction of mesophyll cell size, while leaf thickness and cell size increase in Pisum sativum exposed to this heavy metal (Sandalio et al., 2001). Thus, this experiment was focused on the study the dynamics of photosynthetic parameters of bean (Phaseolus vulgaris L.) and broad bean (Vicia fabo L.) under strong cadmium stress effect.

\section{MATERIALS AND METHODS}

Bean (Phaseolus vulgaris L.) and broad bean (Vicia fabo L.) were chosen for the investigation. Experiments were carried out in a vegetation room with controlled environment: photoperiod $-14 \mathrm{~h}$, average temperature of $20-25^{\circ} \mathrm{C}$, relative humidity - 60\%. "Philips Master Green Power CG T" $600 \mathrm{~W}$ lamps, light intensity at the level of plants $14000 \mathrm{Lx}$ provided light.

P. vulgaris (10 seeds per pot) and $V$. fabo (5 seeds per pot) were sown in a neutral ( $\mathrm{pH} 6.0-$ $6.5)$ peat substrate in $5 \mathrm{~L}$ pots $(21 \mathrm{~cm}$ in diameter). 10 days after germination, when 2 nd true leaf unfolded (at leaf development stage (BBCH12)) (Growth stages..., 2001), growth substrate of $P$. vulgaris and $V$. fabo plants was watered with $6 \mathrm{mM}$ concentration $\mathrm{Cd}_{2} \mathrm{SO}_{4}$ solution. Reference treatment groups were watered with distillated water all the time. In each treatment there were three pots of replication. The treatment variants were chosen according to earlier made experiments at the Environmental Department of the VMU (Januškaitiene, 2012). Duration of the experiment was five days.

The investigated indices: photosynthetic rate, intercellular $\mathrm{CO}_{2}$ concentration, transpiration rate and water use efficiency were measured every day of the experiment. Photosynthetic pigments and dry biomass of shoot 
(foliage) of plants were measured at the end of the experiment.

Gas exchange parameters were measured with portable photosynthesis system LI-6400 (LI-COR, USA). Photosynthetic rate (Pn) $\left(\mu \mathrm{mol} \mathrm{CO} \mathrm{Cm}^{-2} \mathrm{~s}^{-1}\right)$, intercellular $\mathrm{CO}_{2}$ concentration $(\mathrm{Ci})\left(\mu \mathrm{mol} \mathrm{CO} \mathrm{mol} \mathrm{air}^{-1}\right)$, transpiration rate $(\mathrm{Tn})\left(\mathrm{mmol} \mathrm{H}_{2} \mathrm{O} \mathrm{m}^{-2} \mathrm{~s}^{-1}\right)$ and water use efficiency (WUE) $\left(\mu \mathrm{mol} \mathrm{CO} \mathrm{Cm}_{2} \mathrm{mmol}_{2} \mathrm{O}^{-1}\right)$ of second fully expanded leaves were registered every 3 seconds for 10 minutes; from these data a mean of day of measured indices was calculated. Environment conditions during experiments were as follows: air flow rate $-400 \mu \mathrm{mol} \mathrm{s}{ }^{-1}$; block and leaf temperature $-25^{\circ} \mathrm{C}$; $\mathrm{CO}_{2}$ concentration in sample cell - 380-400 $\mu \mathrm{mol} \mathrm{CO}_{2} \mathrm{~mol}^{-1}$; relative humidity in sample cell $-30 \%$; lightness in quant $-190-210 \mu \mathrm{mol} \mathrm{m} \mathrm{m}^{-2} \mathrm{~s}^{-1}$.

The second fully expanded leaves were harvested and photosynthetic pigments were analysed using a spectrophotometer (Genesys 6, ThermoSpectronic, USA) in $100 \%$ acetone extracts prepared according to Wettstein's method (Wettstein, 1957). Photosynthetic pigments were expressed in $\mathrm{mg} \mathrm{g}^{-1}$ of fresh weight.

At the end of the experiment the plants were harvested and dried in an oven at $60{ }^{\circ} \mathrm{C}$ until constant dry foliage biomass was obtained. The biomasses were expressed in mg plant ${ }^{-1}$.
ANOVA was used to determine the effects of cadmium and plant species. And for independent variables comparison Student's $t$ and $U$ tests were used. All analyses were performed by STATISTICA and the results were expressed as mean values and their confidence intervals (CI) $(p<0.05)$.

\section{RESULTS}

The response of $P$. vulgaris and $V$. fabo to cadmium stress was rather different. On the first day of treatment the photosynthetic rate of Cd treated $P$. vulgaris plants decreased only by $4.3 \%$ and statistically insignificant $(\mathrm{p}>0.05)$, while photosynthetic rate of $V$. fabo decreased by $35.9 \%(\mathrm{p}<0.05)$ (Fig. 1$)$. The photosynthetic rate of $P$. vulgaris was decreasing till 3rd day after treatment, when it was $95.9 \%(\mathrm{p}<0.05)$ lower compared to reference treatment. On the contrary, the lowest $(36 \% ; \mathrm{p}<0.05)$, compared to reference treatment, photosynthetic rate of $\mathrm{Cd}$ treated $V$. fabo plants was on the first day and it started to increase from the second day till the last one, when photosynthetic rate in $\mathrm{Cd}$ treated $V$. fabo leaves was only $17.1 \%(\mathrm{p}<0.05)$ less compared to reference treatment.

The highest changes of intercellular $\mathrm{CO}_{2}$ concentration of $P$. vulgaris plants were also detect-

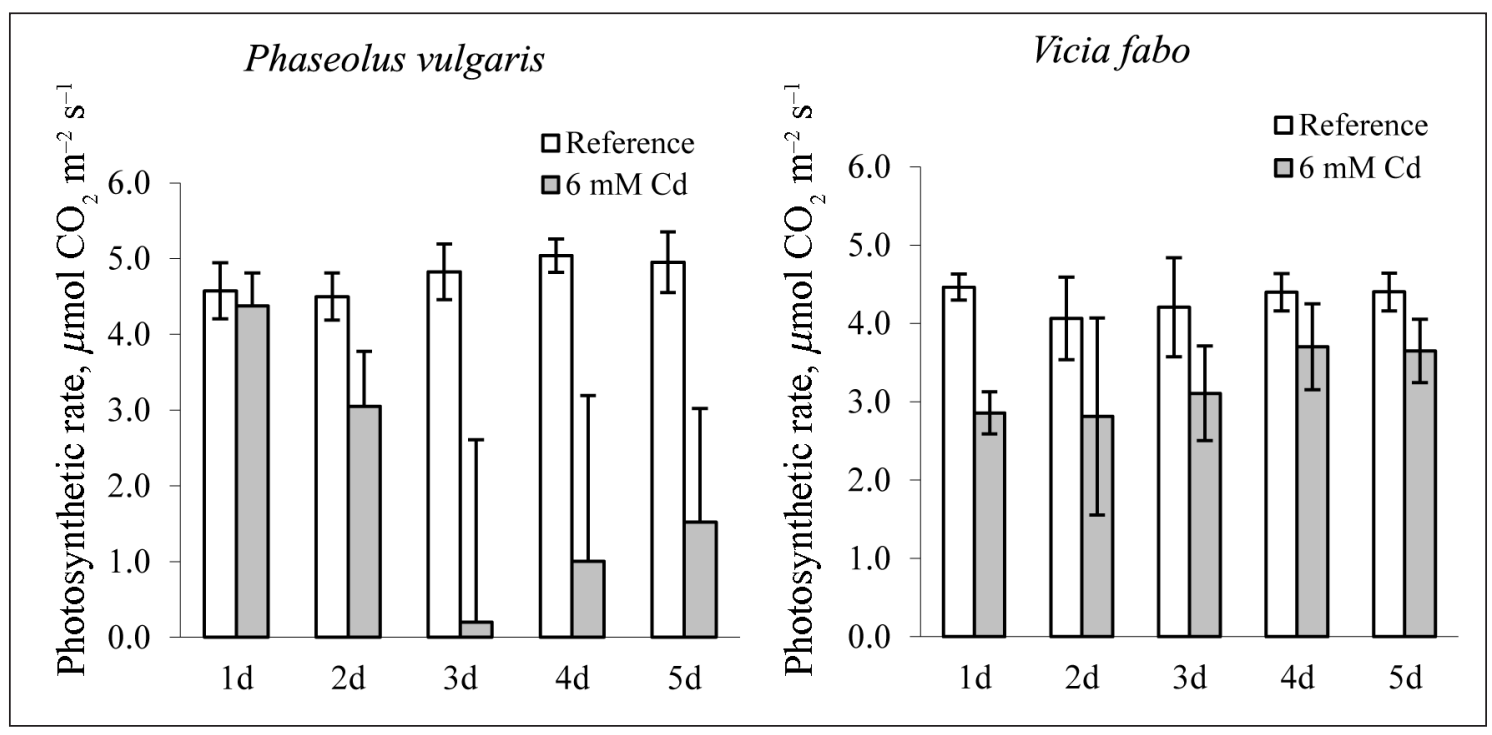

Fig. 1. The dynamics of photosynthetic rate in Phaseolus vulgaris and Vicia fabo leaves after $6 \mathrm{mM} \mathrm{Cd}$ treatment. The values are means $\pm \mathrm{CI}_{0.05}$ 
ed on the third day, when it increased by $70.1 \%$ $(\mathrm{p}<0.05)$ compared to reference treatment (Fig. 2). Higher, compared to reference treatment, intercellular $\mathrm{CO}_{2}$ concentration of $P$. vulgaris was detected on the last day of experiment too, when $\mathrm{Ci}$ increased by $25.8 \%(\mathrm{p}>0.05)$. While the changes of intercellular $\mathrm{CO}_{2}$ concentration of $V$. fabo plants were different, i. e. it decreased by $11.7 \%(\mathrm{p}<0.05)$ and $10.6 \%(\mathrm{p}<0.05)$ on the first and last day, respectively, compared to reference treatment.

The changes of transpiration rate of the investigated plants were different, too. On the first day transpiration rate of $P$. vulgaris increased by $5.4 \%(\mathrm{p}>0.05)$, while transpiration rate of $V$. fabo decreased by $47.6 \%(\mathrm{p}<0.05)$ compared to plants of reference treatment (Fig. 3). The highest decrease of transpira-

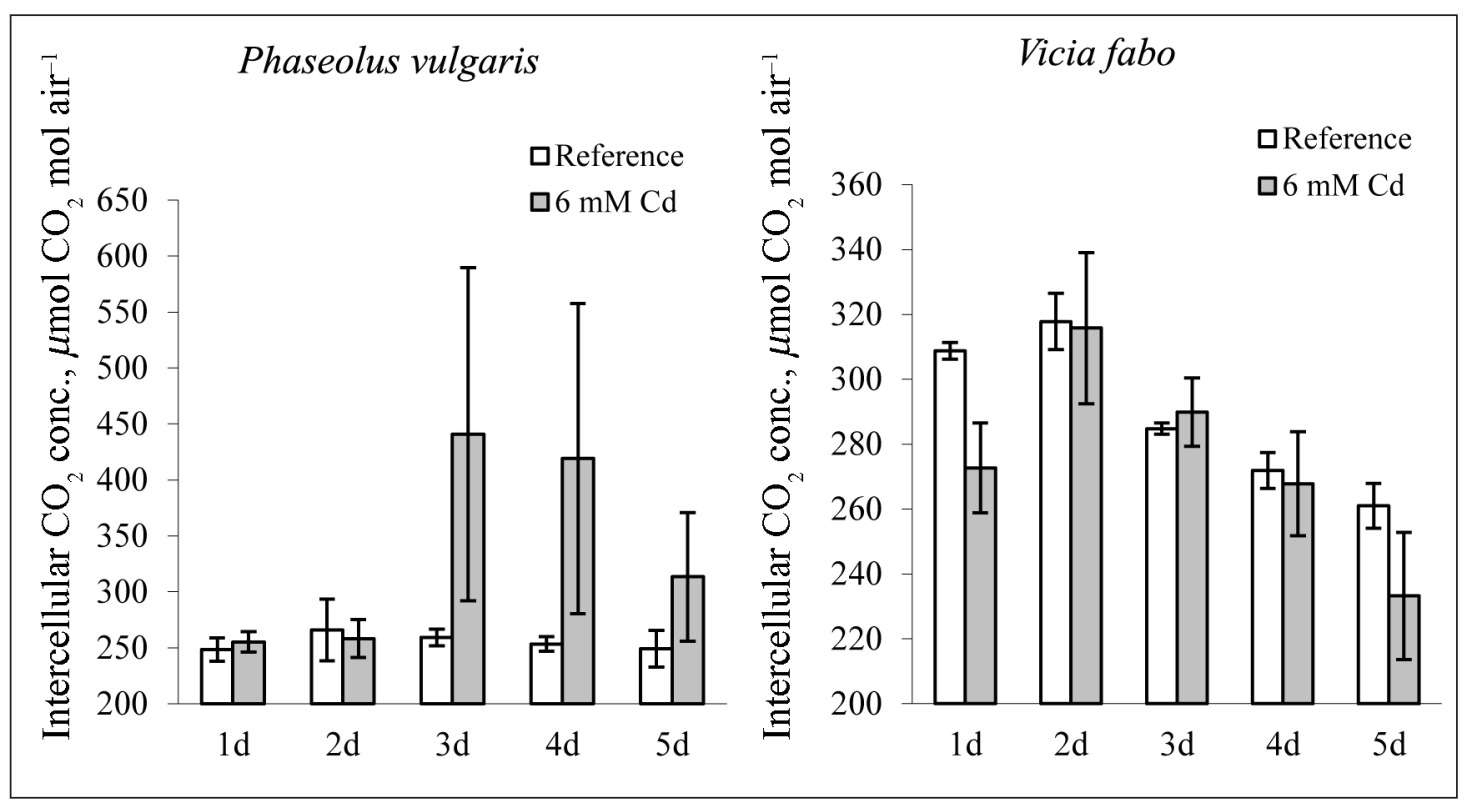

Fig. 2. The dynamics of intercellurlar $\mathrm{CO}_{2}$ concentration in Phaseolus vulgaris and Vicia fabo leaves after $6 \mathrm{mM}$ Cd treatment. The values are means $\pm \mathrm{CI}_{0.05}$

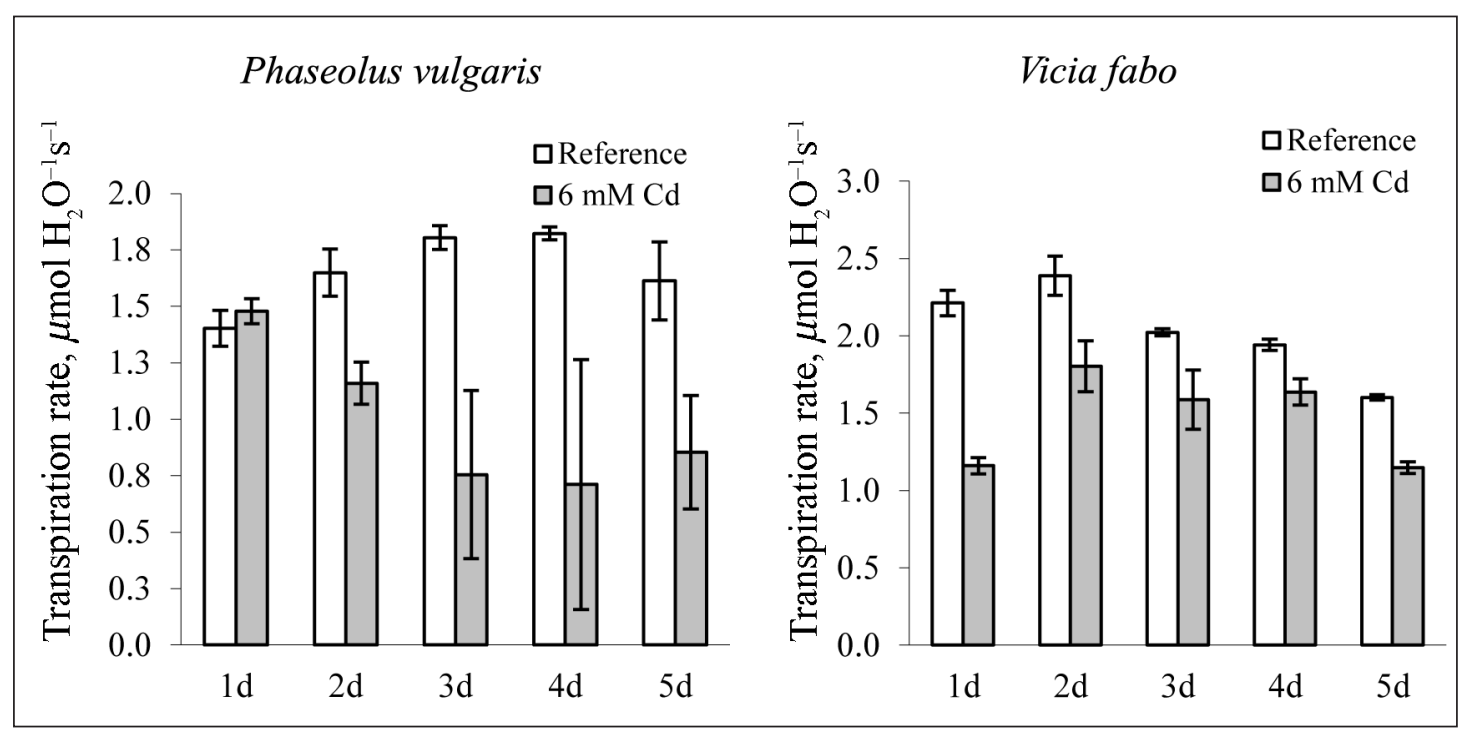

Fig. 3. The dynamics of transpiration rate in Phaseolus vulgaris and Vicia fabo leaves after $6 \mathrm{mM} \mathrm{Cd}$ treatment. The values are means $\pm \mathrm{CI}_{0.05}$ 
tion rate of $P$. vulgaris was detected on the 4 th day of experiment, when it decreased by $61.0 \%(\mathrm{p}<0.05)$ compared to reference. Transpiration rate of $\mathrm{Cd}$ treated $V$. fabo plants was lower, too, on the fourth day, but only $15.7 \%$ ( $\mathrm{p}<0.05)$ compared to reference treatment. On the last day of experiment transpiration rate of Cd treated plants was lower than that of non-treated, and higher decreases were typical for P. vulgaris plants.

Water use efficiency of $\mathrm{Cd}$ treated $P$. vulgaris plants was decreasing till third day, when WUE reached negative values and was more than 2 times lower than in reference plants. WUE of $P$. vulgaris slightly improved on the last one, but still it was $54 \%(\mathrm{p}<0.05)$ lower compared to reference treatment (Fig. 4). While WUE of $V$. fabo plants increased by $23 \%$ $(\mathrm{p}<0.05)$ and $16 \%(\mathrm{p}>0.05)$ on the first and the last day after treatment, respectively, compared to reference.

The content of photosynthetic pigments detected on the last day of the experiment is presented in Fig. 5. Concentration of chorophylls ( $a$ and $b$ ) and carotenoids increased in all Cd treated plant leaves, but statistically insignificant ( $p>0.05)$. The changes of chorophyll $a$ and $b$ ratio of the investigated plants were dif- ferent, i. e. for P. vulgaris it decreased by $5.7 \%$ ( $p>0.05$ ), and for $V$. fabo - increased by $1.4 \%$ $(\mathrm{p}>0.05)$ compared to reference treatment.

The decreases of dry biomass of Cd treated P. vulgaris were higher than V. fabo (Fig. 6). On the fifth day after Cd treatment, the dry biomass of $P$. vulgaris was $44.9 \%(\mathrm{p}<0.05)$ lower compared to reference, and decrease of dry biomass of $V$. fabo was only $0.5 \%$ and statistically insignificant $(p>0.05)$ compared to reference treatment.

\section{DISCUSSION}

As one of the most toxic environmental pollutants cadmium (Cd) has a strong influence on metabolic activities of plants by inducing a number of physiological changes, such as growth inhibition, changes in water and ion metabolism, photosynthesis inhibition, enzyme activity changes, and free radical formation (Jia et al., 2014). Plants use various mechanisms to cope with cadmium, which depends not only on the intensity of stress but also on plant individual characteristics. In this research plants tolerance to $\mathrm{Cd}$ stress was different. V. fabo was more tolerant to cadmium stress than P. vulgaris, but this was seen only on the third day, when photosynthetic

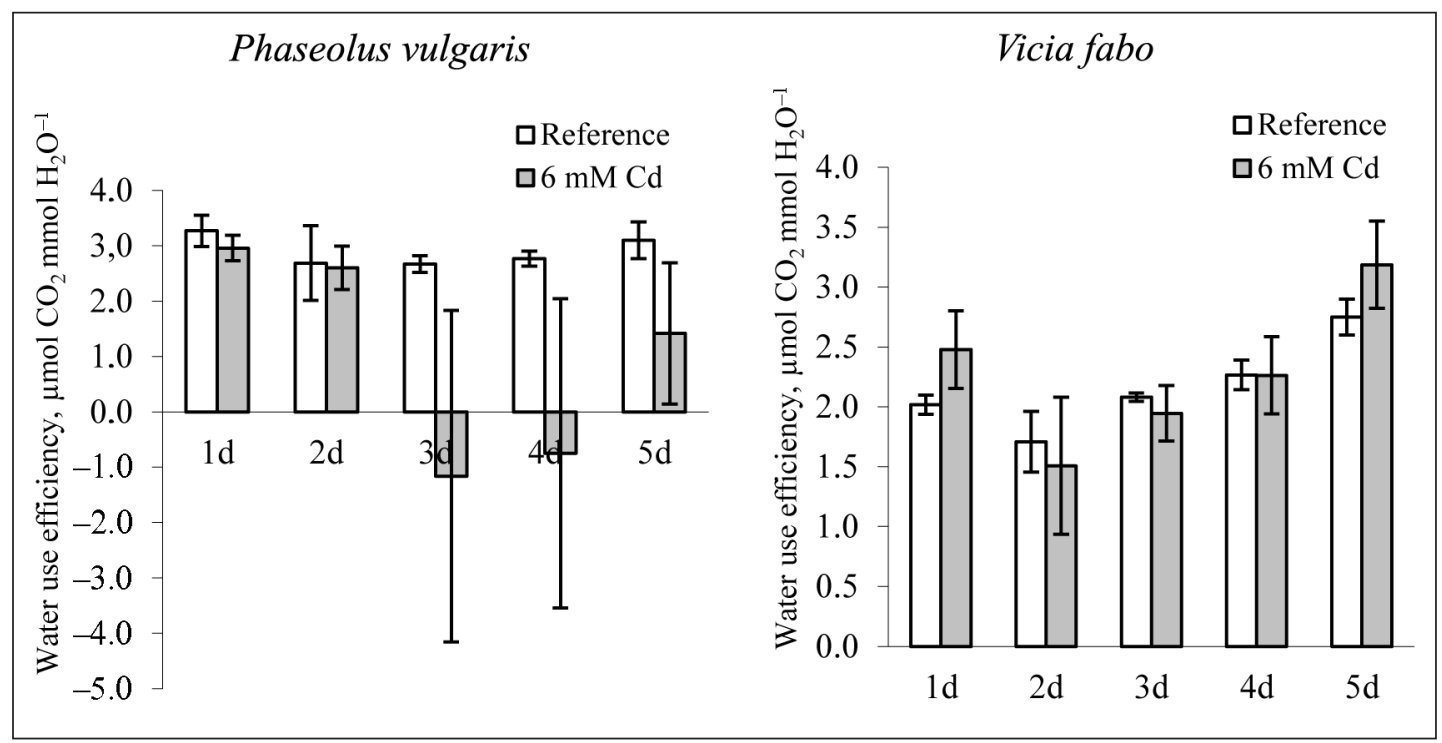

Fig. 4. The dynamics of water use efficiency of Phaseolus vulgaris and Vicia fabo after $6 \mathrm{mM} \mathrm{Cd}$ treatment. The values are means $\pm \mathrm{CI}_{0.05}$ 


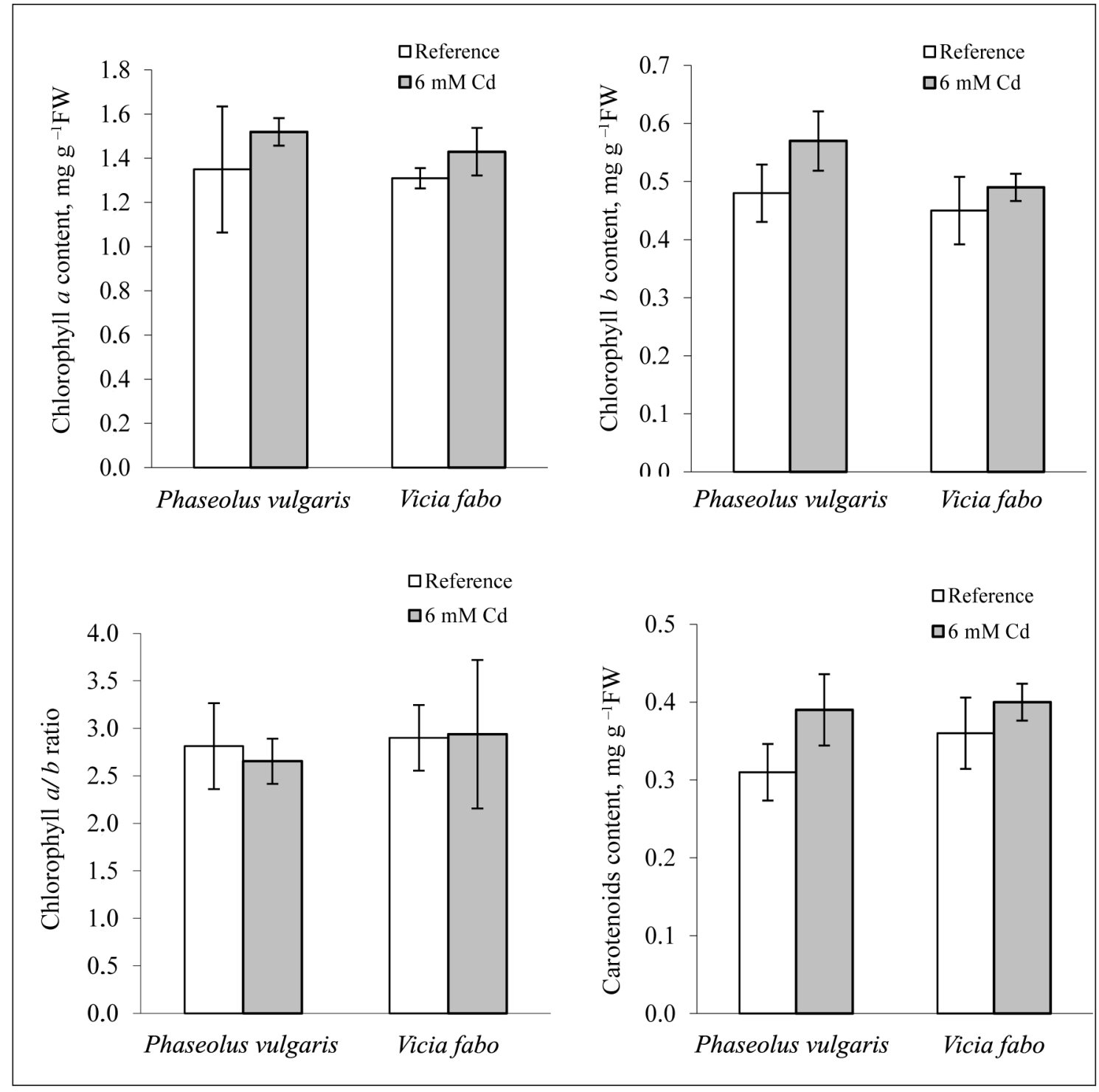

Fig. 5. The changes of chlorophyll $a$, chlorophyll $b$, chlorophyll $a / b$ ratio and carotenoids in Phaseolus vulgaris and Vicia fabo leaves under $6 \mathrm{mM} \mathrm{Cd}$ treatment. The values are means $\pm \mathrm{CI}_{0.05} . \mathrm{FW}$ - fresh weight. The values are means $\pm \mathrm{CI}_{0.05}$

rate of $P$. vulgaris and $V$. fabo plants decreased by $95 \%(\mathrm{p}<0.05)$ and $26 \%(\mathrm{p}<0.05)$ respectively, compared to reference treatment (Fig. 1). Higher negative effect of cadmium on photosynthetic rate of $P$. vulgaris plants stayed on the 5th day after treatment, too. Damages of the photosynthetic apparatus are related to different direct and indirect mechanisms induced by $\mathrm{Cd}$. As a consequence of its capacity to replace essential metals in metal binding proteins, Cd can induce inhibition of chlorophyll (Chl) synthesis and also disturb PSII function (Bertrand, Poirier, 2005; Faller et al., 2005; Kucera et al., 2008). A direct inhibition of $\mathrm{O}_{2}$ evolution by $\mathrm{Cd}$ is also possible (Pagliano et al., 2006). Due to its stable binding to single bondSH groups of proteins, $\mathrm{Cd}$ may interfere directly with enzymes related to $\mathrm{Chl}$ biosynthesis and $\mathrm{C}$ assimilation, and also with the correct assembly of the pigment-protein complexes of both photosystems (Baryla et al., 2001; Basa et al., 2014). Strong effect on enzymatic reaction of photosynthesis also shows a very high intracellular $\mathrm{CO}_{2}$ concentration 


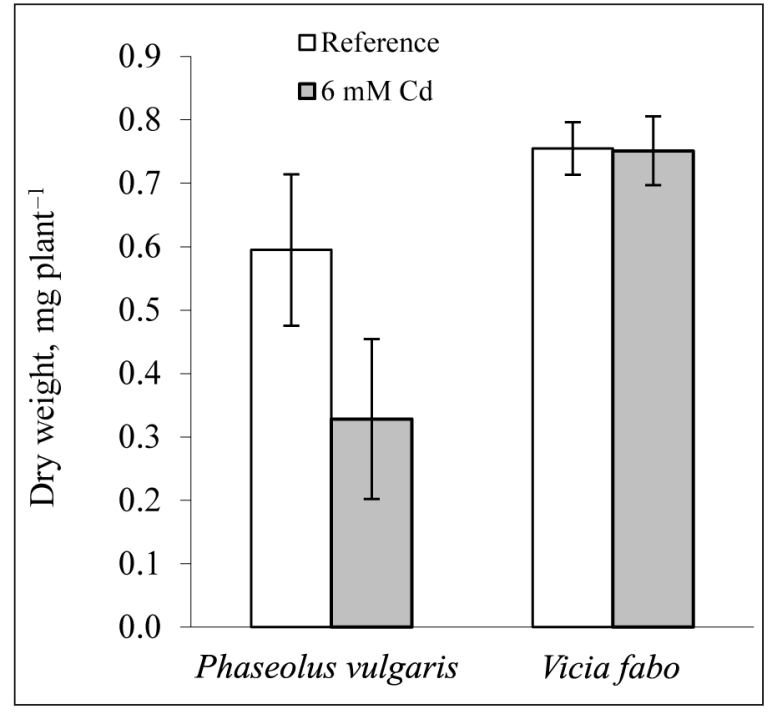

Fig. 6. The changes of dry weight of Phaseolus vulgaris and Vicia fabo under $6 \mathrm{mM} \mathrm{Cd}$ treatment. The values are means $\pm \mathrm{CI}_{0.05}$

(Wahid et al., 2007) in P. vulgaris leaves on the third and fourth day after treatment (Fig. 2). While on these days the changes of intracellular $\mathrm{CO}_{2}$ concentration in $V$. fabo leaves were statistically insignificant.

Toxicity of Cd in plants is associated with reduced water and nutrient uptake (Hassan et al., 2013) and thus reduction in water use efficiency was observed with Cd treatment in P. vulgaris leaves (Fig. 4). This might be due to the inhibition of absorption and translocation of water (Poschenrieder, Barcelo, 1999). Similar results were presented by other researchers, too (Rascio et al., 2008). Also, the water use efficiency of Cd treated V. fabo plants increased. Cadmium may affect stomatal closure in leaves (Wang et al., 2009) and more reduce transpiration rate than photosynthesis, so this caused an increase in WUE of cadmium treated $V$. fabo plants (Fig. 4).

Chlorophylls $a$ and $b$ are important factors of photosynthesis inhibition, and their concentration in plant tissues decreases under abiotic stress environment. It is known that the decrease of chlorophyll content inhibits plant ability to absorb and utilize light energy and, consequently, leads to reduced photosynthesis (Jia et al., 2004).
The content of chlorophylls and carotenoids was postulated as a simple and reliable indicator of heavy metal toxicity for higher plants (Goncalves et al., 2009). But the effects of cadmium on the photosynthetic apparatus are different. In one part of the studies it is presented that $\mathrm{Cd}$ is a potent inhibitor of the photochemical activity of the chloroplasts (Mobin, Khan, 2007), but in another that it is not sensitive to $\mathrm{Cd}$. In this research, the content of chlorophylls and carotenoids increased in all $\mathrm{Cd}$ treated plant leaves, but statistically insignificant ( $p>0.05$ ) (Fig. 5).

Cadmium competes for plant nutrient status and subsequently alters its physiology. High concentrations of Cd decreased the cell growth as well as the plant yield (Irfan et al., 2013). In this research, dry weight of cadmium treated plants decreased, too, but statistically significant only for P. vulgaris (Fig. 6). As has been mentioned above, cadmium damages the photosynthetic apparatus. The data of the current research confirms it too, and a higher negative effect was detected for photosynthetic parameters of $P$. vulgaris plants than of $V$. fabo (Figs. 1-4). So, a contact of plants with Cd leads to the reduction of total photosynthetic area and plant biomass (Lopez-Millan et al., 2009), that is why the changes of dry biomass accumulation were also higher for $P$. vulgaris plants.

\section{CONCLUSIONS}

On the first day of treatment photosynthetic rate of $\mathrm{Cd}$ treated $P$. vulgaris plants decreased only by $4.3 \%$ and was statistically insignificant, while photosynthetic rate of $V$. fabo decreased by $35.9 \%(\mathrm{p}<0.05)$. Photosynthetic rate of $P$. vulgaris was decreasing till $3 \mathrm{rd}$ day after treatment, when it was $96 \%(\mathrm{p}<0.05)$ lower compared to reference treatment. On the contrary, the lowest photosynthetic rate of Cd treated $V$. fabo was on the first day and it started to increase from the second day till the last one.

Water use efficiency of $\mathrm{Cd}$ treated $P$. vulgaris was decreasing till third day and it slightly improved on the last one, but still it was 54\% $(\mathrm{p}<0.05)$ lower compared to reference. While 
water use efficiency of $V$. fabo increased by $23 \%$ $(\mathrm{p}<0.05)$ on the first day, and the changes from the second till fifth day were statistically insignificant.

The changes, detected on the last day of the experiment, of chlorophyll $a$ / $b$ ratio were different too, i. e. for $P$. vulgaris it decreased by $5.7 \%$ ( $p>0.05$ ), and for $V$. fabo - increased by $1.4 \%(\mathrm{p}>0.05)$ compared to reference.

The decreases of dry biomass of $P$. vulgaris were higher than $V$. fabo. On the fifth day after Cd treatment, the dry biomass of $P$. vulgaris was $44.9 \%(\mathrm{p}<0.05)$ lower compared to reference, while the decrease of dry biomass of $V$. fabo was only $0.5 \%(p>0.05)$ compared to reference treatment.

Received 02 June 2014

Accepted 02 September 2014

\section{References}

1. Alkantara E, Romera FJ, Cannete M, De La Guardia MD. Effects of heavy metals on both induction and function of root $\mathrm{Fe}$ (III) reductase in Fe-deficient cucumber (Cucumis sativus L.) plants. J Exper Bot 1994; 45: 1893-8.

2. Barcelo J, Poschenrieder C. Plant water relations as affected by heavy metal stress: a review. J Plant Nutr 1990; 13: 1-37.

3. Baryla A, Carrier P, Frank F, Coulomb C, Sahut C, Havaux M. Leaf chlorosis in oilseed rape plants (Brassica napus) grown on cadmium-polluted soil: causes and consequences for photosynthesis and growth. Planta 2001; 212: 696-709.

4. Basa B, Lattanzio G, Solti A, Toth B, Abadia J, Fodor F, Sarvari E. Changes induced by cadmium stress and iron deficiency in the composition and organization of thylakoid complexes in sugar beet (Beta vulgaris L.). Env Exper Bot 2014; 101: 1-11.

5. Bertrand M, Poirier I. Photosynthetic organisms and excess of metals. Photosynthetica 2005; 42: 345-53.
6. Faller P, Kienzler K, Krieger-Liszkay A. Mechanism of $\mathrm{Cd}^{2+}$ toxicity: $\mathrm{Cd}^{2+}$ inhibits photoactivation of photosystem II by competitive binding to the essential $\mathrm{Ca}^{2+}$ site. Biochim Biophys Acta 2005; 1706: 158-64.

7. Gallego SM, Pena LB, Barcia RA, Azpilicueta CE, Iannone MF, Rosales EP, Zawoznik MS, Groppa MD, Benavides MP. Unravelling cadmium toxicity and tolerance in plants: insight into regulatory mechanisms. Env Exper Bot 2012; 83: 33-46.

8. Goncalves JF, Tabaldi LA, Cargnelutti D, Pereira LB, Maldaner J, Becker AG, Rossato LV, Rauber R, Bagatini MD, Bisognin DA, Schetinger MRC, Nicoloso FT. Cadmium-induced oxidative stress in two potato cultivars. Biometals 2009; 22: 779-92.

9. Growth stages of mono- and dicotyledonous plants. U. Meier (ed.), BBCH monograph, German Federal Biological Research Centre for Agriculture and Forestry 2001. 10-11.

10. Hassan SE, Hijri M, St-Arnaud M. Effect of arbuscular mycorrhizal fungi on trace metal uptake by sunflower plants grown on cadmium contaminated soil. New Biotechn 2013; 30(6): 780-7.

11. Hu PJ, Qiu RL, Senthilkumar P, Jiang D, Chen ZW, Tang YT, Liu FJ. Tolerance, accumulation and distribution of zinc and cadmium in hyperaccumulator Potentilla griffithii. Env Exper Bot 2009; 66: 317-25.

12. Irfan M, Hayat S, Ahmad A, Alyemeni MN. Soil cadmium enrichment: Allocation and plant physiological manifestations. Saudi J Biol Sci 2013; 20(1): 1-10.

13. Januškaitiene I. The effect of cadmium on several photosynthetic parameters of pea (Pisum sativum L.) at two growth stages. Žemdirbyste $=$ Agriculture 2012; 99(1): 73-85.

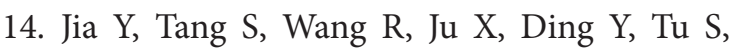
Smith DL. Effects of elevated $\mathrm{CO}_{2}$ on growth, photosynthesis, elemental composition, antioxidant level, and phytochelatin concentration in Lolium mutiforum and Lolium perenne under Cd stress. J Hazar Mater 2014; 180(1-3): 384-94. 
15. Kucera T, Horakova H, Sonska A. Toxic metal ions in photoautotrophic organisms. Photosynthetica 2008 ; 46: 481-9.

16. Li Y, Wang L, Yang L, Li H. Dynamics of rhizosphere properties and antioxidative responses in wheat (Triticum aestivum L.) under cadmium stress. Ecotoxicol Environm Safety 2014; 102: 55-6.

17. Lopez-Climent MF, Arbona V, Perez-Clemente RM, Gomez-Cadenas A. Effects of cadmium on gas exchange and phytohormone contents in citrus. Biol Plantar 2011; 55: 187 90.

18. Lopez-Millan AF, Sagardoy R, Solanas M. Cadmium toxicity in tomato (Lycopersicon esculentum) plants grown in Hydroponics. Env Exper Bot 2009; 65: 376-85.

19. Maksymiec W, Malgorzata W, Krupa Z. Variation in oxidative stress and photochemical activity in Arabidopsis thaliana leaves subjected to cadmium and excess copper in the presence or absence of jasmonate and ascorbate. Chemosphere 2007; 66: 421-7.

20. Mobin M, Khan NA. Photosynthetic activity, pigment composition and antioxidative response of two mustard (Brassica juncea) cultivars differing in photosynthetic capacity subjected to cadmium stress. J Plant Physiol 2007; 164: 601-10.

21. Mohamed AA, Castagna A, Ranieri A, Sanita di Toppi L. Cadmium tolerance in Brassica juncea roots and shoots is affected by antioxidant status and phytochelatin biosynthesis. Plant Physiol Biochem 2012; 57: 15-22.

22. Pagliano M, Raviolo FD, Vecchia R, Gabbrielli C, Gonnelli N, Rascio N et al. Evidence for PSII donor-side damage and photoinhibition induced by cadmium treatment on rice (Oryza sativa L.) J Photochem Photobiol B 2006; 84: $70-8$.

23. Parlak KU, Yilmaz DD. Ecophysiological tolerance of Lemna gibba L. exposed to cadmium. Ecotoxicol Env Safety 2013; 91: 79-85.

24. Popova LP, Maslenkova LT, Yordanova RY, Ivanova AP, Krantev AP, Szalai G, Janda T.
Exogenous treatment with salicylic acid attenuates cadmium toxicity in pea seedlings. Plant Physiol Biochem 2009; 47(3): 224-31.

25. Poschenrieder C, Barcelo J. Water relation in heavy metals stressed plants. Prasad MNV, J. Hagemayer (eds.). Heavy metal stress in plants, from molecules to ecosystems. Berlin, Heidelberg, New York 1999, 207-31.

26. Poschenrieder C, Gunse B, Barcelo J. Influence of cadmium on water relations, stomatal resistance and abscisic acid content in expanding bean leaves. Plant Physiol 1989; 90: 136571.

27. Rascio N, Vecchia FD, La Rocca N, Barbato R, Pagliano C, Raviolo M, Gonnelli C, Gabbrielli R. Metal accumulation and damage in rice (cv. Vialone nano) seedlings exposed to cadmium. Env Exper Bot 2008; 62(3): 267-78.

28. Saidi I, Chtourou Y, Djebali W. Selenium alleviates cadmium toxicity by preventing oxidative stress in sunflower (Helianthus annuus) seedlings. Orig J Plant Physiol 2014; 171(5): 85-91.

29. Sandalio LM, Dalurzo HC, Gomes M. Cadmium-induced changes in the growth and oxidative metabolism of pea plants. J Exper Bot 2001; 52: 2115-26.

30. Siedlecka A, Krupa Z, Samuelsson G, Oquist G, Gardestrom P. Primary carbon metabolism in Phaseolus vulgaris under $\mathrm{Cd} / \mathrm{Fe}$ interaction. Plant Physiol Biochem 1997; 35: 951-7.

31. Templeton DM, Liu Y. Multiple roles of cadmium in cell death and survival. ChemicoBiol Interact 2010; 188: 267-75.

32. Uraguchi S, Mori S, Kuramata M, Kawasaki A, Arao T, Ishikawa S. Root-to-shoot Cd translocation via the xylem is the major process determining shoot and grain cadmium accumulation in rice. J Exper Bot 2009; 60: 2677-88.

33. Valentovicova K, Haluskova L, Huttova J, Mistrik I, Tamas L. Effect of cadmium on diaphorase activity and nitric oxide production in barley root tips. J Plant Physiol 2010; 167: $10-4$. 
34. Wahid A, Ghani A, Ali I. Effects of cadmium on carbon and nitrogen assimilation in shoots of mungbean [Vigna radiate (L.) Wilczek] seedlings. J Agron Crop Sci 2007; 193: 357-65.

35. Wang H, Zhao SC, Liu RL. Changes of photosynthetic activities of maize (Zea mays L.) seedlings in response to cadmium stress. Photosynthetica 2009; 47(2): 277-83.

36. Wettstein D. Chlorophyll Letale und der submikroskopische Formweschsel der Plastiden. Exper Cell Res 1957; 12: 427-432. (in German).

\section{Irena Januškaitienè}

\section{PHASEOLUS VULGARIS IR VICIA FABO FO- TOSINTEZĖS RODIKLIŲ DINAMIKA ESANT STIPRIAM KADMIO STRESUI}

\section{Santrauka}

Kadmis yra vienas toksiškiausių metalų, kurio šaltiniai - cheminès trąšos, dirvožemio tręšimas nuotekų dumblu bei kitomis atliekomis ir emisijos iš atmosferos. Tyrimo tikslas - išsiaiškinti pupelès (Phaseolus vulgaris L.) ir pupos (Vicia fabo L.) fotosintezès rodiklių dinamikos pokyčius esant stipriam kadmio stresui. Augalai sèti ị neutralaus rūgštumo ( $\mathrm{pH} \mathrm{6,0-6,5)}$ substratą, išleidę du tikruosius lapelius buvo paveikti $6 \mathrm{mM} \mathrm{CdSO}_{4}$ koncentracijos tirpalu. Eksperimento trukmè - penkios dienos. Fotosintezès rodikliai (fotosintezès intensyvumas (Pn), transpiracijos intensyvumas (Tn), viduląstelinis $\mathrm{CO}_{2}$ kiekis $(\mathrm{Ci})$ ir vandens naudojimo efektyvumas (WUE)) matuoti kiekvie- ną dieną nešiojama fotosintezès sistema LI-6400. Pigmentų kiekiai lapuose nustatyti acetono ekstrakte spektrofotometriškai paskutinę (5-ą) eksperimento dieną. Pirmą eksperimento dieną kadmiu paveiktų Phaseolus vulgaris fotosintezès intensyvumas sumažèjo statistiškai nereikšmingai - tik 4,3\%, o Vicia fabo Pn - 35,9\% ( $<$ < 0,05). Phaseolus vulgaris Pn mažèjimas tęsèsi iki trečios dienos (po poveikio), kai fotosintezès intensyvumas buvo net $96 \%(\mathrm{p}<0,05)$ mažesnis, palyginti su kontroliniais augalais. Priešingai, kadmiu paveiktų Vicia fabo mažiausias fotosintezès intensyvumas nustatytas pirmą eksperimento dieną, kuris toliau gerèjo iki paskutinès dienos. Kadmiu paveiktų Phaseolus vulgaris vandens naudojimo efektyvumas taip pat mažejo iki trečios dienos, šiek tiek pagerejo paskutinę dieną, bet vis tiek buvo $54 \%$ $(\mathrm{p}<0,05)$ mažesnis nei kontrolinių augalų. Vicia fabo WUE padidejo tiek pirmą (23\%; p < 0,05), tiek ir paskutinę $(16 \%$; $>0,05)$ dieną, palyginti su kontroliniais augalais. Skirtingi chlorofilų $a$ ir $b$ santykio pokyčiai nustatyti paskutinę eksperimento dieną, t. y. Phaseolus vulgaris chl a/b - mažèjo (5, $7 \%$; p > 0,05), o Vicia fabo - didejo (1,4 \%; p > 0,05), palyginti su kontroliniais augalais. Sausos biomasès pokyčiai taip pat buvo didesni Phaseolus vulgaris, o Vicia fabo biomasė kito statistiškai nereikšmingai.

Raktažodžiai: streso dinamika, Cd, fotosintezès intensyvumas, viduląstelinis $\mathrm{CO}_{2}$ kiekis, transpiracija, vandens naudojimo efektyvumas, fotosintetiniai pigmentai, sausa biomasè, Phaseolus vulgaris, Vicia fabo 